\title{
SPECIFIC FEATURES OF THE EFFECT PROVIDED BY BIOSTIMULATION WITH EXOGENOUS AMINO ACID PREPARATIONS ON THE PRODUCTIVITY AND PROPERTIES OF SEA BUCKTHORN FRUIT (HIPPOPHAE L.)
}

\author{
V.G. Verzhuk ${ }^{1}$, A.V. Pavlov ${ }^{1}$, S.V. Murashev' ${ }^{2}$, M.V. Erastenkova ${ }^{2}$ \\ ${ }^{I}$ The N.I. Vavilov Institute of Plant Genetic Resources (VIR), St. Petersburg, Russia, \\ vverzhuk@mail.ru \\ ${ }^{2}$ St. Petersburg State Agricultural University, St. Petersburg - Pushkin, Russia, \\ merastenkova@gmail.com \begin{abstract}
growing season, plant resistance to various diseases, early harvests, and problems of their storage, a promising and effective intervention is the use of growth stimulants. To enhance growth, plants were treated with an amino acid preparation (glycine) at dosage rates 20,40,60,80, 100 and $120 \mathrm{mg} / \mathrm{l}$. The reference sample was treated with water. The experimental samples exceeded the reference in mean fruit weight; the greatest increase of fruit weight and dry matter content was observed in the 5th sample (fruit weight: $0.79 \mathrm{~g}$, dry matter content: 10.2\%). Sample No. 3 contained the highest amount of sugars, with the preparation's dosage $40 \mathrm{mg} / 1: 9.56 \%$, which was higher than the reference by $2.44 \%$ (sample No. 1). This excess refers to monosaccharides and disaccharides. The content of malic, citric, oxalic and tartaric acids in all experimental samples was higher than in the reference; the best results were shown by sample No. 6 , with the dosage $100 \mathrm{mg} / \mathrm{l}$.
\end{abstract} \\ Abstract. In the northwestern agro-ecological region of the country, with its shortened plant
}

Keywords: amino acid preparation (glycine), sea buckthorn berries, sugars, mono- and disaccharides, acids: malic, citric, oxalic and tartaric

DOI: $10.31255 / 978-5-94797-319-8-855-857$

At present, an important role is assigned to exogenous regulation of plant growth and development, which may increase crop productivity and minimize harvest losses during storage. Bioactive substances provide for targeted regulation of physiological processes in plants and help to mobilize the potential embedded into the crop genome by nature and by breeding, but often unavailable for practical implementation. A promising instrument to shorten plant growing seasons and obtain earlier crop yields with high technological qualities and resistance to various diseases both in the field and during storage is the use of plant growth and development stimulants. They do not threaten to breach the ecological balance in the atmosphere, play a significant role in the resistance-aimed strategy, have high economic efficiency, and make it possible to achieve results that are not attainable by other practices or technologies. Amino acid plant growth regulators may appear in the form of a protein hydrolysate consisting of an amino acid/peptide mixture with molecular weight of individual components up to $1000 \mathrm{Da}$. Besides, they may be pure amino acids, such as glycine and alanine, whose efficiency has been studied on crops after treatment in the spring/summer period, and in autumn after harvesting. According to the data of various researchers, physical and chemical properties [Verzhuk, Murahsev, 2009], respiration intensity [Kuznetsov et al., 2005], protective mechanisms [Murashev, 2013], and activity of fermentation processes [Ermakov, 1972; Murashev, Kolomicheva, 2013; Murashev, 2006] can be adjusted with plant growth regulators [Murashev, Sharagova, 2014; Troshin et al., 2004]. It will help to obtain plant products with increased nutritive value and the ability to be stored with minimal losses.

The aim of this work was researching the effect of biostimulation on productivity and fruit properties of the sea buckthorn cultivar Oranzhevaya developed at the M.A. Lisavenko Research Institute of Siberian Horticulture. The experiments were carried out jointly with the Vavilov Institute (VIR) and the Biochemistry Lab of St. Petersburg State Agricultural University. An amino acid preparation (glycine) was chosen as a biostimulant for sea buckthorn berries. Seven plant samples treated by the biostimulant in different concentrations 
in order to study its effect on sea buckthorn productivity and fruit properties. Treatment of sea buckthorn plants was performed at Pushkin/Pavlovsk Laboratories, a Science \& Production Association and a branch of VIR. In the budding phase, at a dry time of the day, the plants were sprinkled with a solution of the preparation in the following concentrations: 20, 40, 60, 80,100 and $120 \mathrm{mg} / \mathrm{l}$ (experiment). Reference plants were treated with similar amounts of water. The stimulant's concentration was regarded as effective, if it was followed synchronously by the greatest increase of fruit weight and the highest content of bioactive substances in berries. The berries harvested in autumn were kept in standard refrigerators at $+2 \ldots+4^{\circ} \mathrm{C}$. Dry matter and water content in sea buckthorn berries was measured by drying them down to a constant weight at the temperature of $105^{\circ} \mathrm{C}$. Organic acids were assessed by titration techniques followed by calculation of their amount. Mean weight of berries was measured by weighing. Optical density was identified on a spectrophotometer; all measurements were made with three replications and computation of a root-mean-square deviation. Weighing was used to assess the mean fruit weight for each dosage of the amino acid growth regulator used for treatments, and for the reference plants.

As a result, the mean weight of one sea buckthorn berry appeared to vary from $0.65 \mathrm{~g}$ to $0.79 \mathrm{~g}$, while in the reference sample (treated only with water) this weight was $0.67 \mathrm{~g}$. The number of berries was selected according to the existing technique [Ermakov et al., 1972].

Table 1.

The effect of treatment with an amino acid growth regulator on the mean fruit weight of a sea buckthorn samples (g)

\begin{tabular}{|c|c|}
\hline Sample & $\begin{array}{c}\text { Mean weight of one } \\
\text { berry, } g\end{array}$ \\
\hline $1($ reference $)$ & 0.67 \\
\hline $2(20 \mathrm{mg} / \mathrm{l})$ & 0.73 \\
\hline $3(40 \mathrm{mg} / \mathrm{l})$ & 0.73 \\
\hline $4(60 \mathrm{mg} / \mathrm{l})$ & 0.65 \\
\hline $5(80 \mathrm{mg} / \mathrm{l})$ & 0.79 \\
\hline $6(100 \mathrm{mg} / \mathrm{l})$ & 0.67 \\
\hline $7(120 \mathrm{mg} / \mathrm{l})$ & 0.66 \\
\hline
\end{tabular}

The obtained data witness that the experimental samples exceeded, as a rule, the reference sample in their mean fruit weight, but the greatest weight increase was observed in the 5th sample $(0.79 \mathrm{~g})$. Analysis of dry matter and water showed that the highest dry matter content was also in the 5th sample: $10.2 \%$ (1.5\% higher than the reference). The 4th sample with the dosage $60 \mathrm{mg} / \mathrm{l}$ showed a very close value $(10,1 \%)$. The concurrence of the data in weight increase and dry matter accumulation in the 5th sample proves the positive effect of biostimulation with amino acid preparations on plant productivity, which in its turn attests to the fact that the photosynthetic apparatus functions with higher efficiency under the influence of biostimulation.

As stated above, the greatest gain in biomass was recorded in the 5th sample, as it demonstrated both the best increase of mean fruit weight and the highest amount of dry matter. As far as the 4th sample is concerned, it showed an increase solely in dry matter content, while its fruit weight was less than in the reference sample, albeit only slightly. The flavor of sea buckthorn berries is determined by the content of carbohydrates (sugars), organic acids, their ratio, and also depends on the composition of carbohydrates, organic acids and other substances themselves. Sea buckthorn berries, according to various data [Salikhov et al., 2011; Plekhanova, 2000] contain 4-11\% of sugars; our experimental samples, in their turn, contained $9.56 \%$ on average or $2.44 \%$ higher than the reference. The same may be said about monosaccharides and disaccharides. The remaining samples did not manifest any tendency towards an increase, except the 7th sample, but it showed only a very slight increase - only $0.44 \%$ higher than the reference. The content of organic acids in sea buckthorn fruit was $1.2-$ 
$3 \%$. According to the data obtained, the content of acids (malic, citric, oxalic and tartaric) was higher in all the samples than in the reference plants, but the highest value was recorded in the 6th sample with the dosage of $100 \mathrm{mg} / \mathrm{l}$. A tendency towards increasing the content of sugars in fruit was observed with the dosage of $40 \mathrm{mg} / \mathrm{l}$. As for organic acids, all dosage rates stimulated an increase in their content.

Table 2.

Gains of biomass in fruit-bearing plant parts expressed through the mean weight of berries and dry matter (g, \%)

\begin{tabular}{|l|c|c|c|c|}
\hline \multicolumn{1}{|c|}{ Sample } & $\begin{array}{c}\text { Gain of mean } \\
\text { weight, } \mathrm{g}\end{array}$ & $\begin{array}{c}\text { Gain of mean } \\
\text { weight, } \%\end{array}$ & $\begin{array}{c}\text { Gain of try } \\
\text { matter, } \mathrm{g}\end{array}$ & $\begin{array}{c}\text { Gain of dry } \\
\text { matter, } \%\end{array}$ \\
\hline $1($ reference $)$ & 0 & 0 & 0 & 0 \\
\hline $2(20 \mathrm{mg} / \mathrm{l})$ & +0.06 & +8.2 & +0.009 & +13.4 \\
\hline $3(40 \mathrm{mg} / \mathrm{l})$ & +0.06 & +8.2 & +0.007 & +10.8 \\
\hline $4(60 \mathrm{mg} / \mathrm{l})$ & -0.02 & -3.1 & +0.007 & +10.8 \\
\hline $5(80 \mathrm{mg} / \mathrm{l})$ & +0.12 & +15.2 & +0.022 & +27.5 \\
\hline $6(100 \mathrm{mg} / \mathrm{l})$ & 0 & 0 & -0.007 & -13.7 \\
\hline $7(120 \mathrm{mg} / \mathrm{l})$ & -0.01 & -1.5 & -0.005 & -9.4 \\
\hline
\end{tabular}

Thus, the described experiments have shown that the use of biostimulants to enhance the growth and development of fruit-bearing plants, when the latter are treated with exogenous amino acid preparations, leads to a considerable increase in plant productivity, provides for safekeeping of the harvest, and adds to its biological value.

List of references

Kuznetsov V.V., Dmitrieva G.A. Plant physiology // Moscow: Vysshaya Shkola, 2005. -736 pp. [available in Russian]

Methods of biochemical plant research. Ed: A.I. Ermakov. - Leningrad: Kolos, 1972. - 456 pp. [available in Russian]

Murashev, S.V. Comparison of the efficiency and safety of protective mechanisms induced in plant organisms // Scientific Journal of ITMO University. Series "Processes and Devices of Food Industries". - 2013. - No. 4. - P. - 28-31. [available in Russian]

Murashev S.V., Kolomicheva E.A. The effect of amino acid treatment on plant dormancy, formation of fruits, and their cold storage (theoretical provisions) // Scientific Journal of ITMO University. Series "Processes and Devices of Food Industries". - 2013. - P. 83-86. [available in Russian]

Murashev S.V., Sharagova N.N. Physical and chemical properties of vegetable and fruit products and special features of their storage in cooled state // Vegetables of Russia. - 2014. - No. 1 (22). - P. 60-61. [available in Russian]

Murashev S.V. Theoretical and experimental research on the regulating effect of a collagen hydrolysate on the formation and cold storage of raw plant materials // Senior Doctorate Thesis (Technological Sciences). - St. Petersburg, 2006. [available in Russian]

Plekhanova M.M. Sea buckthorn. Handbook of a horticulturist. Ed: A.A. Yushev. St. Petersburg, 2000. - P. 250-267. [available in Russian]

Salikhov M.M. et al. Fruit and berry varieties and agricultural practices for the North of Russia. Catalogue of fruit and berry crop plants grown by the Plemzavod Maisky. - AgriProduction Complex, Vologda, 2011. - P. 146-149. [available in Russian]

Troshin L.P., Shcherbak V.S., Gavrilov R.B., Zamanidi P.K., Melnik N.I., Mislivsky A.S. The effect of growth stimulants on the yield and quality of grapevine plants // Polytopical electronic network scientific journal of the Kuban State Agricultural University, 2004. - P. 1-12. [available in Russian]

Verzhuk V.G., Murashev S.V. Modern technology of making fruit and berry produce with reinforced and permanently functioning protective mechanisms // Fruit and Berry Plant Growing in Russia. - 2009. - V. 22, No. 2. - P. 153-158. [available in Russian] 